Publisher: LPPM STIE Muhammadiyah Bandung

P-ISSN: 2541-5255, E-ISSN: 2621-5306

Volume 2 Nomor 3, September - Desember 2018

\title{
ANALISIS MANFAAT AUDIT DITINJAU DARI PERSPEKTIF KLIEN AUDIT
}

(Survei Pada BPR seluruh Kota dan Kabupaten Bandung)

\author{
${ }^{1}$ Erfan Erfiansyah, ${ }^{2}$ Rustandi, Rustandi \\ STIE Muhammdiyah Bandung \\ 1erfanerfiansyah@stiemb.ac.id, ${ }^{2}$ rustandi@stiemb.ac.id
}

\begin{abstract}
ABSTRAK
Penelitian ini bertujuan untuk mengetahui analisis manfaat audit ditinjau dari perspektif klien audit (Survei Pada BPR Kota dan Kabupaten Bandung). Variabel yang diteliti adalah kinerja auditor, tingkat kepuasan klien audit dan manfaat audit bagi para pemangku kepentingan eksternal.

Jenis penelitian ini merupakan penelitian pengujian hipotesis. Penelitian ini menggunakan data kualitatif yang terdiri dari data primer melalui kuesioner, jumlah populasi dalam penelitian ini sebanyak 52 responden. Metode analisis yang digunakan untuk mengukur besarnya pengaruh antar variabel menggunakan Structural Equation Model (SEM) yang berbasis variance atau sering disebut Component Based SEM yang mempergunakan software SmartPLS dan PLS Graph.

Variabel konstruk dari kepuasan kinerja auditor adalah kompetensi auditor, skeptis auditor, hubungan auditor dengan klien, dan hubungan asisten auditor dengan klien yang dipersepsikan klien. Hasil penelitian menunjukkan bahwa Kompetensi Auditor dan Skeptis Auditor terbukti dapat mempengaruhi tingkat kepuasan klien dan manfaat audit bagi para pemangku kepentingan eksternal, sedangkan variabel Hubungan Auditor dengan Klien dan yang dipersepsikan klien dan Hubungan Asisten Auditor dengan Klien yang dipersepsikan klien tidak mempengaruhi kepuasan klien dan manfaat audit bagi para pemangku kepentingan eksternal di di Bank Perkreditan Rakyat seluruh Kota dan Kabupaten Bandung.
\end{abstract}

\section{Kata kunci : Kompetensi Auditor, Skeptis Auditor, Hubungan Asisten Auditor dengan Klien, Tingkat Kepuasan Klien Dan Manfaat Audit Bagi Para Pemangku Kepentingan Eksternal.}

\begin{abstract}
This study aims to determine the audit benefit analysis from the perspective of the client audit (Survey of Bandung City and Regency BPR). The variables studied are auditor performance, the level of audit client satisfaction and audit benefits for external stakeholders.
\end{abstract}


This type of research is a hypothesis testing study. This study uses qualitative data consisting of primary data through questionnaires, the total population in this study were 52 respondents. The analytical method used to measure the magnitude of the influence between variables using Structural Equation Model (SEM) based on variance or often called Component Based SEM that uses SmartPLS and PLS Graph software.

The construct variable of auditor performance satisfaction is auditor competence, auditor skepticism, auditor relationship with client, and assistant auditor relationship with the client perceived by the client. The results showed that the Auditor and Skeptic Competencies of Auditors were proven to influence the level of client satisfaction and audit benefits for external stakeholders, while the variables of Auditor Relations with Clients and perceived clients and Auditor Assistant Relationships with Clients perceived by clients did not affect client satisfaction and audit benefits for external stakeholders at the Rural Bank of all Bandung City and Regency.

\section{Keywords : Auditor Competence, Skeptical Auditor, Auditor Assistant Relationship with Client, Level of Client Satisfaction and Benefits of Audit for External Stakeholders.}

\section{PENDAHULUAN}

Laporan keuangan salah satu media yang mengkomunikasikan fakta-fakta yang terjadi mengenai perusahaan dan sebagai dasar untuk menentukan atau menilai kinerja posisi keuangan perusahaan (suarsa \& Nawawi, 2018). Pemakai laporan keuangan tidak hanya pihak internal perusahaan saja tetapi juga termasuk pihak eksternal perusahaan. Melihat begitu banyaknya pihak yang berkepentingan terhadap informasi yang disajikan pada laporan keuangan, maka informasi yang disajikan pada laporan keuangan tersebut harus wajar dan dapat dipercaya, serta tidak menyesatkan bagi pemakainya sehingga kebutuhan masing-masing pihak yang berkepentingan dapat dipenuhi. Untuk dapat menjamin kewajaran informasi yang disajikan dalam laporan keuangan, perlu adanya suatu pemeriksaan yang dilakukan oleh akuntan publik yang berkualitas. Salah satu pihak yang membutuhkan kualitas audit adalah Bank Perkreditan Rakyat (selanjutnya disebut BPR). Akhir-akhir ini banyak berita terkait dengan kegagalan operasional BPR. Pada tahun 2013, Bank Indonesia telah menutup delapan BPR di Sumatera Barat yang dikarenakan BPR tersebut tidak mampu menjalankan operasionalnya sesuai standar yang telah ditetapkan sehingga dinyatakan sebagai bank gagal. Kasus yang hampir sama juga terjadi di Bali. Pada tahun 2013, Bank Indonesia menutup dua BPR di Bali yaitu BPR Swasad Arta dan BPR Argawa Utama karena dinilai telah membahayakan kelangsungan usahanya. Kedua BPR tersebut tidak menerapkan prinsip kehatihatian dalam menyalurkan kredit sehingga mengakibatkan angka kredit macet mendekati $100 \%$ yang mana akhirnya banyak bermuncul kredit fiktif. Dari berbagai kasus tersebut, bisa dibayangkan apa yang akan terjadi bila BPR tidak mendapatkan pengawasan yang semestinya. Salah satu pihak yang dapat mengevaluasi kegiatan operasionalnya adalah akuntan 
Publisher: LPPM STIE Muhammadiyah Bandung

P-ISSN: 2541-5255, E-ISSN: 2621-5306

Volume 2 Nomor 3, September - Desember 2018

publik. Bank Indonesia (selanjutnya disebut BI) sendiri telah banyak memiliki rekanan dengan Kantor Akuntan Publik (selanjutnya disebut KAP) yang mana KAP yang telah berrekanan dengan $\mathrm{BI}$ adalah KAP telah mendapat rekomendasi dalam mengaudit BPR setiap tahunnya. Auditor KAP seharusnya berperan sebagai jembatan antara pihak manajemen dengan stakeholders, oleh karena itu para ahli berpendapat (Bazerman et. al.(1997); Jenkins and Lowe (1999); Mayhew et. al. (2001); Ohman et. al. (2006)) bahwa auditor harus memiliki loyalitas. Auditor harus bisa melayani para pemilik dan para pemangku kepentingan eksternal, selain itu juga auditor harus bisa memuaskan para manajemen perusahaan. Akan tetapi dalam pelaksanaanya sering terjadi ketegangan antara kepentingan dari para stakeholders dengan kepentingan yang dimiliki manajemen (Ijiri, (1975) dalam Lee, (1993)). Cohen, Krishnamoorthy, \& Wright (2010, 752) menjelaskan bahwa:

$$
\text { "The relationship between }
$$

management and auditors was significantly impacted by the passage of the SarbanesOxley Act (SOX). One key provision of SOX was to shift responsibility for the oversight of auditors, including the decision to hire and fire audit firms, from management to audit committees". Berdasarkan hasil pernyataan yang dikemukakan oleh Sarbanes-Oxley Act (SOX) bahwa meskipun hal tersebut dilakukan untuk meminimalisasi pengaruh dari manajemen terhadap auditor, manajemen tetap memiliki peran kunci dalam penentuan dalam mempekerjakan dan memberhentikan auditor.

Berdasarkan latar belakang yang telah diuraikan sebelumnya dan fenomena yang terjadi di lapangan maka dapat dirumuskan permasalahan dalam penelitian ini adalah sebagai berikut:

1. Apakah kompetensi auditor yang dipersepsikan oleh klien berpengaruh terhadap tingkat kepuasan klien.
2. Apakah kompetensi auditor yang dipersepsikan oleh klien berpengaruh terhadap tingkat manfaat audit bagi para pemangku kepentingan eksternal.

3. Apakah skeptis auditor yang dipersepsikan oleh klien berpengaruh terhadap tingkat kepuasan klien.

4. Apakah skeptis auditor yang dipersepsikan oleh klien berpengaruh terhadap tingkat manfaat audit bagi para pemangku kepentingan eksternal.

5. Apakah hubungan baik antara auditor dengan para kliennya yang dipersepsikan oleh klien berpengaruh terhadap tingkat kepuasan klien.

6. Apakah hubungan baik antara auditor dengan para kliennya yang dipersepsikan oleh klien berpengaruh terhadap tingkat manfaat audit bagi para pemangku kepentingan eksternal.

7. Apakah hubungan baik antara asisten auditor dengan para klien yang dipersepsikan oleh klien berpengaruh terhadap tingkat kepuasan klien.

8. Apakah hubungan baik antara asisten auditor dengan para klien yang dipersepsikan oleh klien berpengaruh terhadap tingkat manfaat audit bagi para pemangku kepentingan eksternal.

\section{KAJIAN PUSTAKA, KERANGKA PEMIKIRAN DAN HIPOTESIS}

Manajemen sebuah perusahaan tentunya bertanggung jawab terhadap stakeholder nya, oleh karena itu stakeholder mempunyai peranan penting dalam penetapan tujuan dari sebuah perusahaan. Adam dalam Nor Hadi (2011) menyatakan sebuah perusahaan pada dasarnya tidak bias melepaskan diri dari lingkungan social. Salah satu bentuk pertanggungjawaban manajemen adalah untuk menjalankan kegiatan perusahaan. Selain itu juga manajemen bertanggungjawab terhadap stakeholder oleh karena itu salah satu bentuk pertanggungjawaban yang digunakan berupa laporan keuangan. Laporan keuangan perusahaan menjadi andal dan 
dapat lebih dipercaya apabila telah melalui tahap pemeriksaan (audit). Audit dilakukan oleh pihak eksternal/ independen yang artinya berada di luar perusaahaan. Terdapat hal-hal yang harus dimilki oleh seorang auditor dalam menjalankan tugasnya karena seorang auditor pada akhirnya akan memberikan output yang akan menjadi dasar untuk menilai kinerja dari manajemen perusahaan tersebut.

Dalam perkembangannya seorang auditor dituntut agar lebih professional dalam menjalankan kewajibannya. Mulyadi (2013) menyatakan bahwa kompetensi dapat diartikan suatu tingkatan pemahaman dan pengetahuan yang memungkinkan seorang untuk memberikan jasa dengan kemudahan dan kecerdikan. Dapat diartikan bahwa kompetensi auditor merupakan sebuah sikap atupun nilai yang harus dimiliki oleh seorang auditor terkait dengan pekerjaannya sebagai auditor, baik secara pengetahuan yang dimilikinya maupun keahlian serta pelatihan teknis yang cukup.Perusahaan dituntut perlunya menjaga legitimasi stakeholder serta menempatkan kedudukan stakeholder tersebut baik dalam pengambilan keputusan maupun yang berhubungan dengan kebijakan perusahaan, sehingga diharapkan dapat menjaga, mendukung, dan memfasilitasi apa yang menjadi tujuan perusahaan salah satunya adalah usaha dan jaminan going concern.

Sikap lain yang harus dimiliki oleh auditor adalah skeptisisme. Menurut Louwers, et al. (2013), skeptisisme merupakan sikap seorang auditor yang tidak percaya terhadap asersi manajemen dengan tidak disertai bukti pendukung yang sifatnya menguatkan. Oleh karena itu, dengan adanya skeptisisme dalam diri auditor akan mengakibatkan analisis yang dilakukan oleh seorang auditor akan lebih bersifat investigative dan lebih tajam dalam membandingkan hasil analisisnya dengan bukti-bukti yang diperoleh. Rasa percaya terhadap objek maupun antar individu dapat terjalin apabila telah mengenal objek atau individu tersebut ukuran waktu dapat dikatakan relative dalam menimbulkan rasa percaya tersebut. Rasa percaya bersifat positif ataupun negative hal tersebut dipengaruhi oleh pengalaman. Pengalaman yang bersifat positif sehingga menambah rasa percaya yang dimiliki, berlaku sebaliknya sifat negatif dapat mengurangi rasa percaya. Tingkat rasa percaya auditor dan klien representatif terbentuk oleh pengalaman sebelumnya antara individu tersebut (Kopp et.al : 2010). Lamanya hubungan auditor dan klien akan mempengaruhi rasa percaya diantara keduanya, lamanya hubungan memiliki kontribusi pengalaman yang dapat dijadikan acuan penilaian auditor terhadap klien dan juga sebaliknya. Hubungan yang lebih baru antara auditor dan klien memiliki kecenderungan lebih meningkatkan sikap kehati-hatian auditor, karena auditor belum memahami sepenuhnya proses bisnis klien dan karakter klien representative.

Menurut Kotler dalam Sunyoto (2013), kepuasan konsumen/ klien adalah tingkat perasaan seseorang mengenai harapan atas hasil pekerjaan, hal tersebut tidak lepas dari proses membandingkan kinerja atau hasil yang diharapkan, yang mana harapan tersebut menjadi dasar penilaian terhadap kinerja atau hasil yang akan menjadi tolak ukur mengenai tingkat kepuasan atau kesesuaian dari harapan tersebut. Konsumen/ klien dapat mengalami salah satu dari tiga tingkat kepuasan umum yaitu kalau kinerja di bawah harapan, konsumen akan merasa kecewa tetapi jika kinerja sesuai dengan harapan pelanggan akan merasa puas dan apa bila kinerja bisa melebihi harapan maka pelanggan akan merasakan sangat puas senang atau gembira.

\section{Gambar Kerangka Pemikiran}


Publisher: LPPM STIE Muhammadiyah Bandung

P-ISSN: 2541-5255, E-ISSN: 2621-5306

Volume 2 Nomor 3, September - Desember 2018

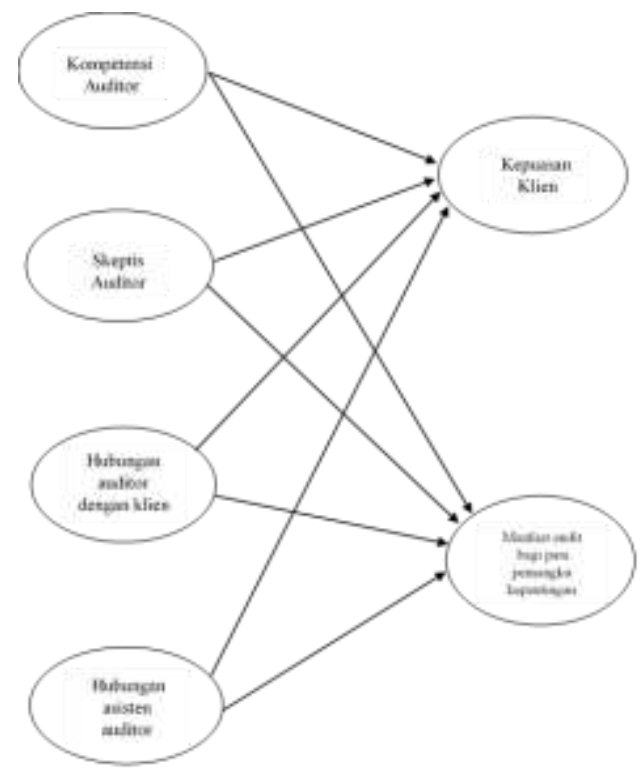

Berdasarkan uraian di atas tersebut maka terbentuk hipotesis sebagai berikut:

H1a. Semakin tinggi kompetensi auditor penanggungjawab yang dipersepsikan oleh para klien, semakin besar kepuasan yang klien peroleh dari audit itu.

H1b. Semakin tinggi kompetensi penanggungjawab auditor dipersepsikan oleh para klien, semakin besar klien percaya bahwa audit bermanfaat bagi para pemangku kepentingan eksternal.

H2a. Semakin skeptis auditor yang dipersepsikan oleh para klien, maka semakin rendah tingkat kepuasan klien terhadap audit.

H2b. Semakin skeptis auditor yang dipersepsikan oleh para klien, maka semakin besar klien percaya bahwa audit bermanfaat bagi para pemangku kepentingan eksternal.

H3a. Semakin baik hubungan dengan auditor penanggungjawab yang dipersepsi oleh para klien, maka mereka semakin puas dengan audit.

H3b. Semakin baik hubungan dengan auditor penenggungjawab yang dipersepsi oleh para klien, maka klien meyakini kurang manfaat audit bagi para pemangku kepentingan eksternal.
H4a. Semakin baik hubungan dengan para asisten audit yang dipersepsi oleh klien maka klien semakin puas dengan audit.

H4b. Semakin baik hubungan dengan para asisten audit yang dipersepsi oleh para klien maka mereka yakin semakin kurang manfaat audit bagi para pemangku kepentingan eksternal.

\section{DESKRIPSI OBJEK PENELITIAN}

Objek penelitian adalah BPR di kota dan kabupaten Bandung yang terdaftar pada Directory BPR Bank Indonesia Jawa Barat pada tahun 2018 yaitu sebanyak 55 BPR. Populasi dalam penelitian ini adalah Karyawan yang bertanggungjawab atas akuntansi dan keuangan, dengan alasan karena Karyawan yang bertanggungjawab atas akuntansi dan keuangan memiliki informasi lengkap dan menyeluruh untuk mengevaluasi kinerja KAP, sebab mereka selalu berhubungan dengan KAP apabila perusahaannya sedang diaudit. Sehingga populasi pada penelitian ini berjumlah 55 responden. Populasi tidak disampling karena jumlah populasi yang sedikit dan untuk memenuhi jumlah minimal agar valid pada saat perhitungan statistik pada program PLS. Untuk pengujian seluruh hipotesis dalam penelitian ini digunakan SEM.

\section{DESAIN DAN METODE PENELITIAN}

Penelitian ini menggunakan penelitian yang bersifat kausal (Sebabakibat). Desain penelitian kausal digunakan untuk mengetahui hubungan sebab-akibat dari variabel-variabel yang diteliti untuk menjawab pertanyaan peneliti. Dalam penelitian ini dilakukan dua jenis pengukuran variabel, yaitu:

1. Skala nominal, untuk mengukur klasifikasi identitas profile responden seperti usia, pendidikan terakhir, jenis kelamin, masa kerja dan jabatan.

2. Skala interval, untuk mengukur variable dependen dan independen yaitu 
kompetensi auditor, skeptic auditor, hubungan auditor denga klien, hubungan asisten auditor dengan klien, kepuasan klien, manfaat audit bagi para pemangku kepentingan eksternal dengan menggunakan skala linkert yaitu skor 1 5.

\section{Gambar}

\section{Model Penelitian}

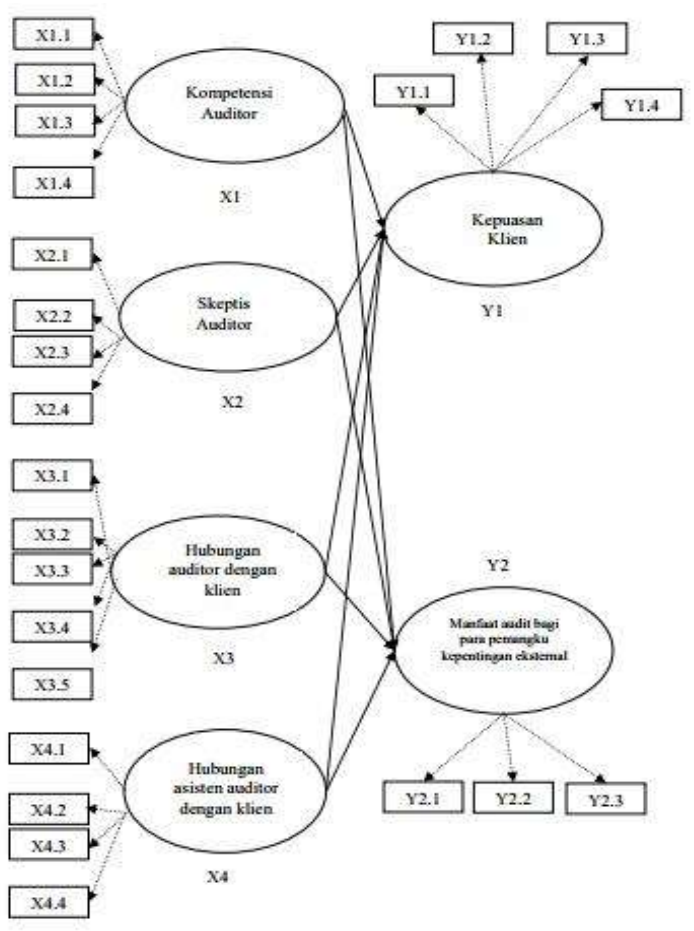

Adapun indikator - indikator pertanyaan dari setiap variabel adalah sebagai berikut:

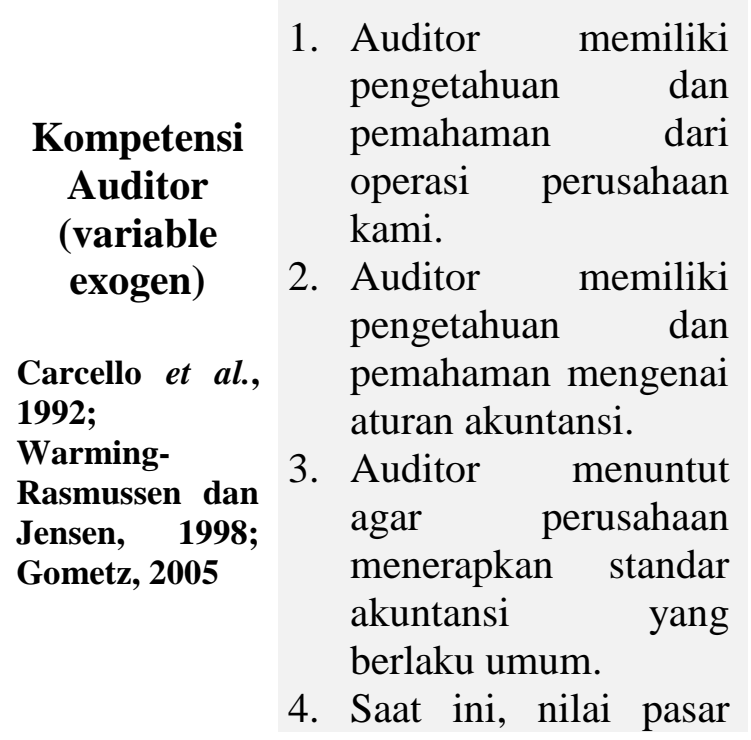

harus diterapkan untuk aset. Saya menganggap

kemampuan auditor untuk menilai nilai pasar aset sangat baik.

1. Sikap auditor sangat skeptis (curiga) terhadap perusahaan.

2. Pendapat yang dikeluarkan auditor sering menimbulkan situasi konflik antara aturan akuntansi dengan kepentingan perusahaan.

3. Auditor memahami dan fleksibel ketika membahas masalah (terkait pertanyaan B2).

4. Asisten auditor memiliki sikap skeptis (curiga) terhadap perusahaan.

1. Auditor hampir setiap hari mengunjungi perusahaan.

2. Auditor menunjukkan komitmen yang besar dalam kontrak kerja dengan perusahaan.

\section{Hubungan Auditor dengan Klien (variable exogen)}

3. Hubungan kami dengan auditor bersifat informal dan pribadi.

4. Hubungan kami dengan auditor ditandai dengan kontrak kerjasama audit.

5. Misalkan Anda menemukan sesuatu di perusahaan yang berada di batas 
legalitas, tapi mungkin tidak akan terdeteksi oleh audit. Dalam situasi ini, Anda secara spontan dan segera akan memberitahu auditor tentang pengamatan ini.

\begin{tabular}{|c|c|}
\hline $\begin{array}{l}\text { Hubungan } \\
\text { asisten } \\
\text { auditor } \\
\text { dengan klien } \\
\text { (variable } \\
\text { exogen) }\end{array}$ & $\begin{array}{l}\text { 1. Asisten } \\
\text { hampir setiap hari } \\
\text { mengunjungi } \\
\text { perusahaan. } \\
\text { 2. Asisten audit } \\
\text { mengambil beban } \\
\text { kerja dalam audit } \\
\text { perusahaan menjadi } \\
\text { pertimbangan besar } \\
\text { bagi kami. } \\
\text { 3. Hubungan dengan } \\
\text { asisten audit kami } \\
\text { bersifat informal dan } \\
\text { pribadi. } \\
\text { 4. Hubungan kami } \\
\text { dengan asisten audit } \\
\text { ditandai dengan } \\
\text { kontrak kerjasama } \\
\text { audit. }\end{array}$ \\
\hline
\end{tabular}

1. Anda puas dengan kualitas jasa audit perusahaan Anda.

\begin{tabular}{|c|c|}
\hline $\begin{array}{l}\text { Kepuasan } \\
\text { Klien } \\
\text { (variable } \\
\text { endogen) }\end{array}$ & $\begin{array}{l}\text { 2. Anda puas dengan } \\
\text { harga jasa audit } \\
\text { perusahaan Anda. } \\
\text { 3. Menurut anda dewan } \\
\text { direksi dan }\end{array}$ \\
\hline $\begin{array}{l}\text { Behn et al., } \\
1997 ; \text { Carcello } \\
\text { et al., 1998; } \\
\text { Pandit, } 1999 ; \\
\text { Ismael et al., } \\
2006\end{array}$ & 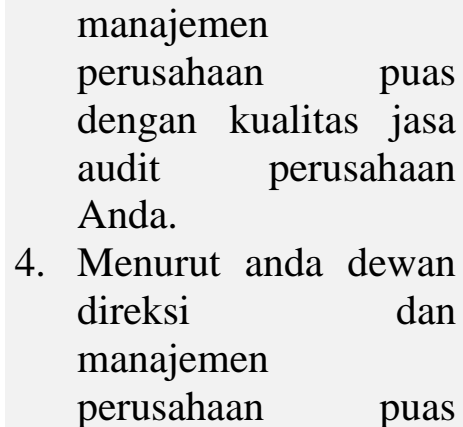 \\
\hline
\end{tabular}

dengan harga jasa audit perusahaan Anda.

1. Penting bahwa auditor tidak memihak dan independen, dan bekerja dengan integritas dan objektivitas.

Para

Pemangku

Kepentingan

Eksternal

(variable endogen)

Catasus dan Grojer, 2005

2. Auditor harus lebih memperhatikan dan kemampuan perusahaan untuk bertahan hidup (going concern).

3. Menurut anda pemilik puas dengan kualitas jasa audit perusahaan Anda. mengevaluasi

Metode Analisis yang digunakan adalah Structural Equation Model (SEM) yang berbasis variance atau sering disebut Component Based SEM yang mempergunakan software SmartPLS dan PLS Graph. Oleh karena itu untuk menguji uji $t$ atau juga untuk menguji signifikansi konstanta dan variabel independen yang terdapat dalam persamaan tersebut secara individu apakah berpengaruh terhadap nilai variabel dependen (Imam Ghozali, 2011). Untuk pengujian ini dilakukan dengan melihat output dengan bantuan program aplikasi PLS Graph. Jika nilai T hitung < T tabel, maka Hipotesis nol ditolak, (koefisien regresi signifikan) dan Hipotesis alternatif yang dinyatakan dalam penelitian ini diterima pada tingkat signifikansi 5\% (lima persen). Pengukuran persentase pengaruh semua variabel independen terhadap nilai variabel dependen, ditunjukkan oleh besarnya koefisien determinasi R-square (R2) antara 1 dan nol, dimana nilai $\mathrm{R}$ square (R2) yang mendekati satu 
Publisher: LPPM STIE Muhammadiyah Bandung

P-ISSN: 2541-5255, E-ISSN: 2621-5306

Volume 2 Nomor 3, September - Desember 2018

memberikan persentase pengaruh yang besar.

\section{PEMBAHASAN}

Kuesioner yang berisi 24 item pertanyaan ini sudah digunakan oleh beberapa peneliti terdahulu, yang mana keabsahan dan kesahihannya telah terbukti memadai. Pertanyaan ini disebarkan kepada 55 responden melalui 55 kantor BPR seluruh Kota dan Kabupaten Bandung. Penyebaran kuesioner dilakukan secara langsung kepada responden dan dikirimkan melalui pos. Namun, untuk mengantisipasi tingkat pengembalian yang rendah dari responden, peneliti berupaya menindaklanjuti dengan mendatangi secara langsung sebagian responden.

Gambaran mengenai subyek penelitian digunakan tabel distribusi frekuensi dalam jumlah dan prosentase. Responden sebanyak 55 responden atau $100 \%$ menjalankan tugasnya sebagai Kepala Akuntansi di BPR. Profil responden disajikan sebagai berikut:

\section{Profil Responden}

\begin{tabular}{|c|c|c|c|c|}
\hline \multirow{4}{*}{$\begin{array}{c}\text { No } \\
1\end{array}$} & \multirow{2}{*}{\multicolumn{2}{|c|}{ Keterangan }} & & \\
\hline & & & Jumlah & Prosentase (\%) \\
\hline & \multicolumn{2}{|c|}{ Jabatan } & 55 & 100 \\
\hline & $\mathrm{a}$ & $\begin{array}{l}\text { Kepala } \\
\text { Bagian } \\
\text { Akuntansi }\end{array}$ & 55 & 100 \\
\hline \multirow[t]{3}{*}{2} & \multicolumn{2}{|c|}{ Jenis Kelamin } & 55 & 100 \\
\hline & $\mathrm{a}$ & Pria & 34 & 61.82 \\
\hline & $\mathrm{b}$ & Wanita & 21 & 38.18 \\
\hline \multirow[t]{4}{*}{3} & \multicolumn{2}{|c|}{ Umur } & 55 & 100 \\
\hline & $\mathrm{a}$ & $\begin{array}{l}20 \text { s.d. } 30 \\
\text { tahun }\end{array}$ & 10 & 18.18 \\
\hline & $\mathrm{b}$ & $\begin{array}{l}31 \text { s.d. } 40 \\
\text { tahun }\end{array}$ & 15 & 27.27 \\
\hline & $\mathrm{c}$ & $\begin{array}{ll}\text { Lebih } & \\
\text { dari } & 40 \\
\text { tahun } & \end{array}$ & 30 & 54.55 \\
\hline \multirow[t]{5}{*}{4} & \multicolumn{2}{|c|}{ Lama Bekerja } & 55 & 100 \\
\hline & $\mathrm{a}$ & $\begin{array}{l}\text { Dibawah } \\
5 \text { tahun }\end{array}$ & 4 & 7.27 \\
\hline & $\mathrm{b}$ & $\begin{array}{l}6 \text { s.d. } 10 \\
\text { tahun }\end{array}$ & 12 & 21.82 \\
\hline & $\mathrm{c}$ & $\begin{array}{l}11 \text { s.d. } 20 \\
\text { tahun }\end{array}$ & 32 & 58.18 \\
\hline & d & $\begin{array}{l}\text { Diatas } 21 \\
\text { tahun }\end{array}$ & 7 & 12.73 \\
\hline
\end{tabular}

Sumber : Data Primer yang diolah
Dalam penelitian ini, faktor yang diteliti mencakup 4 (faktor) faktor, yaitu: kompetensi auditor, skeptisisme auditor, hubungan auditor dengan klien, hubungan asisten auditor dengan klien (Libby dan Tan, 1994). Berdasarkan hasil output PLS Graph, maka masing-masing konstruk dapat di urutkan berdasarkan nilai estimates (koefisien) dari masing-masing konstruk yaitu sebagai berikut:

Urutan Konstruk Berdasarkan Nilai Estimates

\begin{tabular}{|c|l|c|}
\hline No & \multicolumn{1}{|c|}{ Konstruk } & Estimates \\
\hline 1 & Kompetensi auditor & 0.519325 \\
\hline 2 & Kompetensi auditor & 0.426133 \\
\hline 3 & Skeptis auditor & 0.413468 \\
\hline 4 & Skeptis auditor & 0.451929 \\
\hline 5 & $\begin{array}{l}\text { Hubungan auditor dengan } \\
\text { klien }\end{array}$ & 0.173133 \\
\hline 6 & $\begin{array}{l}\text { Hubungan auditor dengan } \\
\text { klien }\end{array}$ & 0.111888 \\
\hline 7 & $\begin{array}{l}\text { Hubungan asisten auditor } \\
\text { dengan klien }\end{array}$ & 0.003508 \\
\hline 8 & $\begin{array}{l}\text { Hubungan asisten auditor } \\
\text { dengan klien }\end{array}$ & 0.001906 \\
\hline
\end{tabular}

Sumber : Output Program PLS Graph yang diolah

Menilai inner model adalah mengevaluasi hubungan antar konstruk laten seperti yang telah dihipotesiskan dalam penelitian ini. Tabel di bawah ini menunjukkan nilai koefesien hubungan antara konstruk, tingkat signifikasi dan nilai $R$-square yaitu sebagai berikut:

Estimate, Standard Error Dan T Statistik

\begin{tabular}{|c|c|c|c|c|}
\hline Path & $\begin{array}{c}\text { Estimate } \\
\text { s }\end{array}$ & $\begin{array}{c}\text { Standar } \\
\text { d Error }\end{array}$ & $\begin{array}{c}\text { T- } \\
\text { Statistic }\end{array}$ & $\begin{array}{c}\text { R- } \\
\text { Square }\end{array}$ \\
\hline $\begin{array}{c}\text { Kompetens } \\
\text { i Auditor - } \\
>\end{array}$ & 0.519325 & 0.087426 & 5.940142 & \\
$\begin{array}{c}\text { Kepuasan } \\
\text { Klien }\end{array}$ & & 0.090684 & 4.559423 & \\
\hline $\begin{array}{c}\text { Skeptis } \\
\text { Auditor -> } \\
\text { Kepuasan } \\
\text { Klien }\end{array}$ & 0.413468 & & \\
\hline $\begin{array}{c}\text { Hubungan } \\
\text { Auditor } \\
\text { dengan } \\
\text { Klien -> } \\
\text { Kepuasan } \\
\text { Klien }\end{array}$ & 0.173133 & 0.113695 & 1.522786 & \\
\cline { 1 - 3 } $\begin{array}{c}\text { Hubungan } \\
\text { Assisten } \\
\text { Auditor } \\
\text { dengan } \\
\text { Klien -> }\end{array}$ & 0.003508 & 0.113026 & 0.031034 & \\
\hline
\end{tabular}


Publisher: LPPM STIE Muhammadiyah Bandung

P-ISSN: 2541-5255, E-ISSN: 2621-5306

Volume 2 Nomor 3, September - Desember 2018

\begin{tabular}{|c|c|c|c|c|}
\hline Path & $\begin{array}{c}\text { Estimate } \\
\mathrm{s}\end{array}$ & $\begin{array}{l}\text { Standar } \\
\text { d Error }\end{array}$ & $\begin{array}{c}\text { T- } \\
\text { Statistic }\end{array}$ & $\begin{array}{c}\text { R- } \\
\text { Square }\end{array}$ \\
\hline $\begin{array}{c}\text { Kepuasan } \\
\text { Klien }\end{array}$ & & & & \\
\hline $\begin{array}{c}\text { Kompetens } \\
\text { i Auditor - } \\
>\text { Manfaat } \\
\text { Audit }\end{array}$ & 0.426133 & 0.092800 & 4.591940 & \multirow{4}{*}{0.499494} \\
\hline $\begin{array}{c}\text { Skeptis } \\
\text { Auditor -> } \\
\text { Manfaat } \\
\text { Audit }\end{array}$ & 0.451929 & 0.098813 & 4.573585 & \\
\hline $\begin{array}{c}\text { Hubungan } \\
\text { Auditor } \\
\text { dengan } \\
\text { Klien -> } \\
\text { Manfaat } \\
\text { Audit }\end{array}$ & 0.111888 & 0.124349 & 0.899795 & \\
\hline $\begin{array}{c}\text { Hubungan } \\
\text { Assisten } \\
\text { Auditor } \\
\text { dengan } \\
\text { Klien -> } \\
\text { Manfaat } \\
\text { Audit }\end{array}$ & 0.001906 & 0.127626 & 0.014930 & \\
\hline
\end{tabular}

Sumber : Output Program PLS Graph

Koefisien Parameter I

\begin{tabular}{|c|c|c|c|}
\hline & $\boldsymbol{\lambda}$ & $\begin{array}{c}\text { T } \\
\text { Statistics }\end{array}$ & R-square \\
\cline { 1 - 3 } Hub asaud klien -> Kep klien & 0,004 & 0,031 & \\
\cline { 1 - 3 } Hub aud klien -> Kep klien & 0,173 & 1,523 & \multirow{2}{*}{0,602} \\
\cline { 1 - 3 } Kom aud -> Kep klien & 0,519 & 5,940 & \\
\cline { 1 - 3 } Skep aud -> Kep klien & 0,413 & 4,559 & \\
\hline
\end{tabular}

$* *$ signifikan pada taraf nyata $0,05, \mathrm{t}_{\text {tabel }}=1,96$

$$
\begin{aligned}
\mathbf{Y} 1= & 0,004 \mathbf{X}_{1}+0,173 \mathbf{X}_{2}+0,519 \mathbf{X}_{3}+ \\
& 0,413 \mathbf{X}_{4}+\mathbf{0 , 3 9 8}
\end{aligned}
$$

\section{Koefisien Parameter II}

\begin{tabular}{|c|c|c|c|}
\hline & $\boldsymbol{\lambda}$ & $\begin{array}{c}\mathbf{T} \\
\text { Statistic } \\
\mathbf{S}\end{array}$ & $\begin{array}{c}\text { R- } \\
\text { square }\end{array}$ \\
\cline { 1 - 3 } $\begin{array}{c}\text { Hub asaud klien -> Manfaat } \\
\text { audit }\end{array}$ & $\begin{array}{c}0,00 \\
2\end{array}$ & 0,015 & \multirow{2}{*}{0,499} \\
\cline { 1 - 3 } Hub aud klien -> Manfaat audit & $\begin{array}{c}0,11 \\
2\end{array}$ & 0,900 & \\
\cline { 1 - 3 } Kom aud -> Manfaat audit & $\begin{array}{c}0,42 \\
6\end{array}$ & 4,592 & \\
\cline { 1 - 2 } Skep aud -> Manfaat audit & $\begin{array}{c}0,45 \\
2\end{array}$ & 4,574 & \\
\hline
\end{tabular}

$* *$ signifikan pada taraf nyata $0,05, \mathrm{t}_{\text {tabel }}=1,96$

$$
\begin{aligned}
\mathbf{Y} 1= & 0,002 \mathbf{X}_{1}+0,112 \mathbf{X}_{2}+0,426 \mathbf{X}_{\mathbf{3}}+ \\
& 0,452 \mathbf{X}_{4}+\mathbf{0 , 5 0 1}
\end{aligned}
$$

Dari tabel diatas terlihat jelas bahwa konstruk Kompetensi Auditor dan Skeptis Auditor mempengaruhi Kepuasan Klien dimana $\mathrm{T}$ hitung $>\mathrm{T}$ tabel 1,98, sedangkan konstruk Hubungan Auditor dengan Klien dan Hubungan Asisten Auditor dengan
Klien tidak mempengaruhi Kepuasan Klien dimana $\mathrm{T}$ hitung $<\mathrm{T}$ tabel 1,98. Konstruk Kompetensi Auditor dan Skeptis Auditor mempengaruhi Manfaat Audit Bagi Para Pemangku Kepentingan Eksternal dimana T hitung $>\mathrm{T}$ tabel 1,98, sedangkan Hubungan Auditor dengan Klien dan Hubungan Asisten Auditor dengan Klien tidak mempengaruhi Kepuasan Klien dimana $\mathrm{T}$ hitung $<\mathrm{T}$ tabel 1,98.

Sedangkan nilai R-square (R2) yang terdapat pada tabel 5.18 memiliki nilai R2 sebesar 0.602 dan 0.499 yang berarti bahwa variabel Kompetensi Auditor, Skeptis Auditor, Hubungan Auditor dengan Klien, dan Hubungan Asisten Auditor dengan Klien mampu menjelaskan $60,2 \%$ dari perubahan pada variabel Kepuasan Klien dan sisanya sebesar 39,8\% dipengaruhi oleh faktor-faktor lain. Sedangkan variabel Kompetensi Auditor, Skeptis Auditor, Hubungan Auditor dengan Klien, dan Hubungan Asisten Auditor dengan Klien mampu menjelaskan 49,9\% dari perubahan pada variabel Manfaat Audit Bagi Para Pemangku Kepentingan Eksternal dan sisanya sebesar 50,1\% dipengaruhi oleh faktor-faktor lain.

Uji hipotesis antara variabel-varibel Kompetensi Auditor, Skeptis Auditor,

\begin{tabular}{|c|c|c|c|c|}
\hline \multicolumn{5}{|c|}{ Hasil Uji Hipotesis } \\
\hline $\begin{array}{l}\text { Hipotesi } \\
\text { s }\end{array}$ & Konstruk & $\begin{array}{c}\text { Estimate } \\
\text { s }\end{array}$ & $\underset{\text { Statistik }}{\mathbf{T}}$ & $\underset{\mathbf{n}}{\text { Keputusa }}$ \\
\hline $1 \mathrm{a}$ & $\begin{array}{c}\text { Kompetens } \\
\text { i Auditor -> } \\
\text { Kepuasan } \\
\text { Klien }\end{array}$ & 0.519325 & $\begin{array}{c}5.94014 \\
2\end{array}$ & $\begin{array}{l}\text { Hipotesis } \\
\text { 1a diterima }\end{array}$ \\
\hline $1 \mathrm{~b}$ & $\begin{array}{c}\text { Skeptis } \\
\text { Auditor -> } \\
\text { Kepuasan } \\
\text { Klien }\end{array}$ & 0.413468 & $\begin{array}{c}4.55942 \\
3\end{array}$ & $\begin{array}{l}\text { Hipotesis } \\
\text { 1b diterima }\end{array}$ \\
\hline $2 \mathrm{a}$ & $\begin{array}{c}\text { Hubungan } \\
\text { Auditor } \\
\text { dengan } \\
\text { Klien -> } \\
\text { Kepuasan } \\
\text { Klien }\end{array}$ & 0.173133 & $\begin{array}{c}1.52278 \\
6\end{array}$ & $\begin{array}{l}\text { Hipotesis } \\
\text { 2a ditolak }\end{array}$ \\
\hline $2 b$ & $\begin{array}{c}\text { Hubungan } \\
\text { Assisten } \\
\text { Auditor } \\
\text { dengan } \\
\text { Klien -> } \\
\text { Kepuasan }\end{array}$ & 0.003508 & $\begin{array}{c}0.03103 \\
4\end{array}$ & $\begin{array}{l}\text { Hipotesis } \\
2 \mathrm{~b} \text { ditolak }\end{array}$ \\
\hline
\end{tabular}
Hubungan Auditor dengan Klien, dan Hubungan Asisten Auditor dengan Klien terhadap Kepuasan Klien sebagai berikut : 
Publisher: LPPM STIE Muhammadiyah Bandung

P-ISSN: 2541-5255, E-ISSN: 2621-5306

Volume 2 Nomor 3, September - Desember 2018

\begin{tabular}{|c|c|c|c|c|}
\hline $\begin{array}{l}\text { Hipotesi } \\
\text { s }\end{array}$ & Konstruk & $\begin{array}{c}\text { Estimate } \\
\text { s }\end{array}$ & $\underset{\text { Statistik }}{\mathbf{T}}$ & $\begin{array}{c}\text { Keputusa } \\
\text { n }\end{array}$ \\
\hline & Klien & & & \\
\hline $3 a$ & $\begin{array}{c}\text { Kompetens } \\
\text { i Auditor -> } \\
\text { Manfaat } \\
\text { Audit }\end{array}$ & 0.426133 & $\begin{array}{c}4.59194 \\
0\end{array}$ & $\begin{array}{c}\text { Hipotesis } \\
\text { 3a diterima }\end{array}$ \\
\hline $3 b$ & $\begin{array}{c}\text { Skeptis } \\
\text { Auditor -> } \\
\text { Manfaat } \\
\text { Audit }\end{array}$ & 0.451929 & $\begin{array}{c}4.57358 \\
5\end{array}$ & $\begin{array}{c}\text { Hipotesis } \\
\text { 3b diterima }\end{array}$ \\
\hline $4 a$ & $\begin{array}{c}\text { Hubungan } \\
\text { Auditor } \\
\text { dengan } \\
\text { Klien -> } \\
\text { Manfaat } \\
\text { Audit }\end{array}$ & 0.111888 & $\begin{array}{c}0.89979 \\
5\end{array}$ & $\begin{array}{l}\text { Hipotesis } \\
\text { 4a ditolak }\end{array}$ \\
\hline $4 b$ & $\begin{array}{c}\text { Hubungan } \\
\text { Assisten } \\
\text { Auditor } \\
\text { dengan } \\
\text { Klien -> } \\
\text { Manfaat } \\
\text { Audit }\end{array}$ & 0.001906 & $\begin{array}{c}0.01493 \\
0\end{array}$ & $\begin{array}{l}\text { Hipotesis } \\
\text { 4b ditolak }\end{array}$ \\
\hline
\end{tabular}

Sumber : Output Program PLS Graph yang diolah

Berdasarkan hasil uji hipotesis dari empat variabel konstruk yang mempengaruhi variabel Kepuasan Klien dan Manfaat Audit yaitu Kompetensi Auditor, Skeptis Auditor, Hubungan Auditor dengan Klien dan Hubungan Asisten Auditor dengan Klien hanya terdapat dua variable yang memiliki pengaruh yang signifikan terhadap Kepuasan Klien dan Manfaat Audit yaitu terdapat pada variabel Kompetensi Auditor dan Skeptis Auditor. Hal itu mendukung penelitian yang dilakukan oleh Hellman (2006), Daugherty dan Tervo (2008), dan Cameran (2010) yang menyatakan bahwa kompetensi dan skeptis merupakan kemampuan/ kecakapan teknis yang harus dimiliki oleh setiap auditor dimana pada akhirnya akan mempengaruhi output dari hasil audit tersebut. Secara keseluruhan hasil audit yang dilakukan oleh audit independen dapat dimanfaatkan sebaikbaiknya oleh pihak manajemen.

Sedangkan dua variabel konstruk lainnya yaitu Hubungan Auditor dengan Klien dan Hubungan Asisten Auditor dengan Klien tidak memiliki pengaruh signifikan terhadap Kepuasan Klien dan Manfaan Audit. Hal tersebut membantah penelitian yang dilakukan Bazerman et al.,1997; Jenkins dan Lowe, 1999; Mayhew et al., 2001; Ohman et al.,2006, akan tetapi mendukung penelitian yang dilakukan oleh Ridwan, Soni dan Sukma (2016) yang menyatakan bahwa akibat dari auditor memiliki independensi dan sikap hati-hati dalam kegiatan pemeriksaan berdampak pada sulitnya auditor diajak berkomunikasi sehingga akan menyebabkan perasaan tidak puas dari klien.

Nilai $R$-square (R2) yang terdapat pada tabel 4.18 memiliki nilai $\mathrm{R} 2$ sebesar 0.602 dan 0.499 yang berarti bahwa variabel Kompetensi Auditor, Skeptis Auditor, Hubungan Auditor dengan Klien, dan Hubungan Asisten Auditor dengan Klien mampu menjelaskan $60,2 \%$ dari perubahan pada variabel Manfaat Audit dan sisanya sebesar $39,8 \%$ dipengaruhi oleh faktor-faktor lain. Sedangkan variabel Kompetensi Auditor, Skeptis Auditor, Hubungan Auditor dengan Klien, dan Hubungan Asisten Auditor dengan Klien mampu menjelaskan 49,9\% dari perubahan pada variabel Manfaat Audit Bagi Para Pemangku Kepentingan sedangkan sisanya sebesar $50,1 \%$ dipengaruhi oleh faktorfaktor lain, hal ini sesuai dengan fenomena yang terjadi yang diuraikan pada bab sebelumnya yaitu Auditor harus memiliki loyalitas (Bazerman et al.,1997; Jenkins dan Lowe, 1999; Mayhew et al., 2001; Ohman et al.,2006). Para auditor harus melayani para pemilik dan para pemangku kepentingan eksternal, sementara itu para auditor juga harus memuaskan para manajer perusahaan (karena klien audit juga). Menurut Jenkins dan Lowe (1999), para auditor sendiri memandang loyalitas auditor dengan beberapa sudut pandang. Beberapa auditor memiliki persepsi tentang diri mereka sebagai "pengawas" yang melayani kepentingan para pemangku kepentingan eksternal, sementara para auditor lainnya mempersepsikan diri mereka sebagai "penasehat" para klien.

\section{SIMPULAN, IMPLIKASI, DAN SARAN} Berdasarkan hasil penelitian Kompetensi Auditor dan Skeptis Auditor terbukti dapat mempengaruhi tingkat 
Publisher: LPPM STIE Muhammadiyah Bandung

P-ISSN: 2541-5255, E-ISSN: 2621-5306

Volume 2 Nomor 3, September - Desember 2018

kepuasan klien dan manfaat audit bagi para pemangku kepentingan eksternal di Bank Perkreditan Rakyat seluruh Kota dan Kabupaten Bandung. Variabel Hubungan Auditor dengan Klien dan yang dipersepsikan klien dan Hubungan Asisten Auditor dengan Klien yang dipersepsikan klien tidak mempengaruhi kepuasan klien dan manfaat audit bagi para pemangku kepentingan eksternal di di Bank Perkreditan Rakyat seluruh Kota dan Kabupaten Bandung.

Penelitian ini menunjukkan bahwa auditor dan kantor akuntan yang mendapatkan keuntungan dari fokus pada hubungan klien dan auditor. Hubungan dengan auditor dan asisten audit yang dirasakan oleh klien dipelajari positif akibat dari tidak mempengaruhi kepuasan klien, selain itu juga tidak secara signifikan mempengaruhi kegunaan kepada para pemangku kepentingan eksternal. Namun, sifat-sifat yang berbeda dari tugas auditor dan asisten auditor (Westerdahl, 2005; Hellman, 2006) dapat membantu auditor dan kantor akuntan untuk saling percaya. Sebuah hubungan klien dengan auditor yang baik difasilitasi oleh sifat khusus dari hubungan (Jenkins dan Lowe, 1999; Hellman, 2006) dan dengan perilaku yang ramah terhadap klien (de Ruyter dan Wetzels, 1999). Asisten audit dapat menjalin hubungan baik dengan klien dengan mengambil beban kerja yang diaudit perusahaan menjadi pertimbangan dan membangun kontak informal dan kooperasi dengan perwakilan dari perusahaan yang diaudit. Tugas utama auditor adalah untuk bertindak sebagai wakil pemilik dan memberikan pendapat yang independen dalam laporan audit (Catasu's dan Gro“jer, 2005). Tugas ini mungkin sulit untuk dicapai ketika mencoba untuk membangun hubungan yang baik dengan perwakilan dari perusahaan yang diaudit.

Tiga keterbatasan penelitian ini menunjukkan isu-isu yang pantas untuk penelitian masa depan. Pertama, pemahaman kita tentang faktor-faktor penentu kepuasan klien dan manfaat audit bagi para pemangku kepentingan eksternal masih jauh dari sempurna. Penelitian ini difokuskan pada tingkat auditor dan tim audit dan digunakan sejumlah variabel independen dan pertanyaan tentang masingmasing variabel. Dengan demikian, adalah mungkin untuk meramalkan proyek penelitian masa depan bertujuan untuk memperbaiki dan memperpanjang SEM yang disajikan dalam penelitian ini. Faktorfaktor tambahan, seperti etika auditor, moralitas, dan kejujuran, telah diidentifikasi dalam literatur (Windsor dan Ashkanasy, 1995; Shafer et al, 2001;. Kornish dan Levine, 2004). Kedua, temuan secara eksklusif berkaitan dengan sudut pandang klien audit. Mengenai hubungan antara kepuasan klien dan manfaat audit bagi para pemangku kepentingan eksternal, akan lebih produktif untuk mengeksplorasi hubungan antara kedua variabel. Penelitian masa depan bisa memeriksa sudut pandang pemilik dan pemangku kepentingan eksternal lainnya, dengan mengacu pada kepuasan klien dan manfaat bagi para pemangku kepentingan eksternal. Ketiga, karena semua variabel diukur hanya pada satu titik waktu, sulit untuk membuat pernyataan tentang kausalitas; pernyataan tersebut hanya dapat melanjutkan dari studi longitudinal. Dengan demikian, hal itu akan menarik untuk mempelajari persepsi berbagai pihak dari waktu ke waktu, menganalisis hubungan sebab-akibat yang disarankan oleh SEM.

\section{DAFTAR PUSTAKA}

Abdolmohammadi, M. dan A. Wright. (1987). An Examination of Experience and Task Complexity on Audit Judgements. The Accounting Review. (Januari). Vol. LXII No. 1.

Arens, Alvin A and Loebbecke,James K. (1997). Auditing: An Integrated Approach. 7'th edition. Ney Jersey: Prentice-Hall. 
Publisher: LPPM STIE Muhammadiyah Bandung

P-ISSN: 2541-5255, E-ISSN: 2621-5306

Volume 2 Nomor 3, September - Desember 2018

Azwar,Saifuddin. (2004). Metode Penelitian. Yogyakarta: Pustaka Pelajar.

Bame-Aldred, C.W. and Kida, T. (2007). "A comparison of auditor and client initial negotiation positions and tactics". Accounting, Organizations and Society, Vol. 32 No. 6, pp. 497511.

Bank Indonesia. (2006). Peraturan Bank Indonesia Nomor 8/20/PBI/2006. Jakarta: Bank Indonesia.

Bazerman, M.H., Morgan, K.P. and Loewenstein, G.F. (1997). "The impossibility of auditor independence". Sloan Management Review, Vol. 38 No. 4, pp. 89-94.

Beattie, V. and Fearnley, S. (1995). "The importance of audit firm characteristics and the drivers of auditor change in UK listed companies". Accounting and Business Research, Vol. 25, pp. 227-39.

Beattie, V., Brandt, R. and Fearnley, S. (1999). "Perceptions of auditor independence: UK evidence". Journal of International Accounting, Auditing and Taxation, Vol. 8 No. 1, pp. 67-107.

Beattie, V., Fearnley, S. and Brandt, R. (2001). Behind Closed Doors: What Company Audit Is Really About, Palgrave, Basingstoke.

Beattie, V., Fearnley, S. and Brandt, R. (2004). "A grounded theory model of auditor-client negotiations". International Journal of Auditing, Vol. 8 No. 1, pp. 1-19.

Beattie, V., S. Brown., D. Ewer., B. John., S. Manson., D. Thomas., and M. Tuner. (2001). Extraordinary Item And Income Smoothing, A Positive Accounting Aproach. Journal Of Business Finance and Accounting. Vol. 21 September

Behn, B.K., Carcello, J.V., Hermanson, D.R. and Hermanson, R.H. (1997). "The determinants of audit client satisfaction among clients of big 6 firms". Accounting Horizons, Vol. 11 No. 1, pp. 7-24.

Behn, B.K., Carcello, J.V., Hermanson, D.R. and Hermanson, R.H. (1999). "Client satisfaction and big 6 audit fees". Contemporary Accounting Research, Vol. 16 No. 4, pp. 587608.

Butt, J. L. (1988). "Frequency Judgement in an Auditing related Tasks". Journal of Accounting Research 26. Autumn; 315-350

Cameran, M., Moizer, P. and Pettinicchio, A. (2010). "Customer satisfaction, corporate image, and service quality in professional services". The Service Industries Journal, Vol. 30 No. 3, pp. 421-35.

Carcello, J.V., Hermanson, D.R. and Hermanson, R.H. (1998). "Factors associated with audit client relationships at risk". Journal of Professional Services Marketing, Vol. 17 No. 1, pp. 29-42.

Carcello, J.V., Hermanson, R.H. and McGrath, N.T. (1992). "Audit quality attributes: the perceptions of audit partners, preparers and financial statement users". Auditing: A Journal of Practice and Theory, Vol. 11 No. 1, pp. 45-67.

Catasus, B. and Grojer, J.-E. (2005). "Revisorn kommer till bolagssta"mman - men var a"r revisionen?" ("The auditor visits the general meeting - but where is the audit?"), in Johansson, S.-E., Ha“ckner, E. and Wallerstedt, E. (Eds), Uppdrag revision: Revisorsprofessionen i takt med fo" rva" ntningarna? (The Task of Auditing: A Profession That Lives up to Expectations?), SNS Fo“rlag, Stockholm, pp. 103-21.

Chin, W.W. (1998). "The Partial Least Squares Approach for Structural Equation Modeling". In Marcoulides, G.A. (Ed), Modern 
Publisher: LPPM STIE Muhammadiyah Bandung

P-ISSN: 2541-5255, E-ISSN: 2621-5306

Volume 2 Nomor 3, September - Desember 2018

Method for Business Resaearch, Mahwah. NJ. Erlbaum Associates, hal. $295-358$.

Cohen, J., G. Krishnamoorthy, and A. Wright. (2010). Corporate governance in the post SarbanesOxley era: Auditor experiences. Contemporary Accounting Research 26 (1): 65122.

Daugherty, B.E. and Tervo, W.A. (2008). "Auditor changes and audit satisfaction: client perceptions in the Sarbanes-Oxley era of legislative restrictions and involuntary auditor change". Critical Perspectives on Accounting, Vol. 19 No. 7, pp. 93151.

de Ruyter, K. and Wetzels, M. (1999). "Commitment in auditor-client relationships: antecedents and consequences". Accounting, Organizations and Society, Vol. 24 No. 1, pp. 57-75.

DeAngelo, L. (1981). "Auditor size and audit quality". Journal of Accounting and Economics, Vol. 3 No. 3, pp. 183-99.

DeAngelo, L. (1988). "Managerial competition, information cost, and corporate governance: the use of accounting performance measures in proxy contests". Journal of Accounting and Economics, Vol. 10 No. 1, pp. 3-42.

DeAngelo.L.E, (1981), Auditor Size and Audit Quality. Journal of Accounting \& Economics 3 (December): 183-191.

DeFond, M., \& Zhang, J. (2014). A review of archival auditing research. Journal of Accounting and Economics, 58, 275-326.

Donnelly, D.O., Quirin, J.J. and O'Bryan, D. (2003). "Auditor acceptance of dysfunctional audit behavior: an explanatory model using auditors personal characteristics”. Behavioral
Research in Accounting, Vol. 15 No. 1, pp. 87-110.

Dreyfus, H.L \& S.E Dreyfus. (1986). "Mind Over Machine: The Power Of Human Intuition And Expertise In the Era The Computer". (The Free Press).

Duff, A. (2004). AUDITQUAL: Dimensions of Audit Quality. The Institute of Chartered Accountants of Scotland, Edinburgh.

Eklov, G. (2001). "Auditability as interface: negotiation and signification of intangibles". School of Business Research Reports No. 2001:09, School of Business, Stockholm University, Stockholm.

Ghozali, Imam. (2011). “Aplikasi Analisis Multivariate Dengan Program SPSS". Semarang: Badan Penerbit Universitas Diponegoro.

Gometz, U. (2005). "Va"rden och penningbega" $\mathrm{r}$ - ett

revisorsdilemma" ("Values and craving for money: an auditor's dilemma"), in Nord, G. and Thorell, P. (Eds), Intressekonflikter och finansiella marknader (Conflicts of Interests and Financial Markets), Iustus Fo“rlag, Stockholm, pp. 16283.

Gul, F. and Tsui, J. (1992). "An empirical analysis of Hongkong bankers' perceptions of auditor ability to resist management pressure in an audit conflict situation". Journal of International Accounting, Auditing and Taxation, Vol. 1 No. 2, pp. 17790.

Hadi, Nor. (2011). Corporate Social Responsibility. Yogyakarta : Graha Ilmu.

Hair, Joseph F. et al. (1998). Multivariate Data Analysis. New Jersey: Prentice-Hall, Inc.

Hayes-Roth, F., D. A. Waterman, et al., Eds. (1983). Building Expert Systems. Reading, MA, AddisonWesley. 
Publisher: LPPM STIE Muhammadiyah Bandung

P-ISSN: 2541-5255, E-ISSN: 2621-5306

Volume 2 Nomor 3, September - Desember 2018

Hellman, N. (2006). "Auditor-client interaction and client usefulness: a Swedish case study". International Journal of Auditing, Vol. 10 No. 2, pp. 99-121.

Humphrey, C., Moizer, P. and Turley, W. (1993). "The audit expectation gap in Britain: an empirical investigation". Accounting and Business Research, Vol. 23 No. 91A, pp. 395-411.

Ijiri, Y. (1975). Theory of Accounting Measurement.

American

Accounting Association, Sarasota, FL.

Ikatan Akuntan Indonesia. (2001). Standar Profesional Akuntan Publik. Jakarta: Salemba Empat.

Imam Ghozali. (2006). Aplikasi Analisis Multivariat Dengan Program SPSS, Cetakan Keempat. Badan Penerbit Universitas Diponegoro, Semarang.

Imam Ghozali. (2006). Aplikasi Structural Equation Modeling, Metode Alternatif dengan Partial Least Square (PLS), Edisi Pertama, Badan Penerbit Universitas Diponegoro, Semarang.

Ismail, I., Haron, H., Ibrahim, D.N. and Isa, S.A. (2006). "Service quality, client satisfaction and loyalty towards audit firms: perceptions of Malaysian public listed companies". Managerial Auditing Journal, Vol. 21 No. 7, pp. 738-56.

Iyer, V.M. and Rama, D.V. (2004). 'Clients' expectations on audit judgments: a note". Behavioral Research in Accounting, Vol. 16, pp. 63-74.

Jenkins, J.G. and Lowe, D.J. (1999). "Auditors as advocates for their clients: perceptions of the auditorclient relationship". Journal of Applied Business Research, Vol. 15 No. 2, pp. 73-8.

Jo"reskog, K.G. and So“rbom, D. (1989). LISREL 7: A Guide to the Program and Application, Scientific Software International, Chicago, IL.

Kee, H. W., Knox, R. E. (1970). "Conceptual and Methodological Consideration in the Study of Trust and Suspicion." The Journal of Conflict Resolution. Vol.14, No.3 : 357-366.

Komite SPAP Ikatan Akuntan Indonesia. (2001). Standar Profesi Akuntan Publik. Salemba Empat. Jakarta.

Kopp. Bryan, Cerbin , Bill. 2014. A Brief introduction to Collage Lesson Study. Lesson Study Project. http://www.ewlax.edu/sot/lsp/index $2 \mathrm{htm}$.

Kotler, P. (2005). Manajemen Pemasaran. Edisi 11, Jilid 1. Gramedia Pustaka Utama, Jakarta.

Lee, T.A. (1993). Corporate Audit Theory, Chapman \& Hall, London.

Lee, Tom \& Mary Stone. (1995). "Competence and Independence: The Congenial Twins of Auditing?". Journal of Business Finance and Accounting. 22 (8). December. pp1169-1177.

Libby, R. and Tan, H.T. (1994). "Modelling the determinants of audit expertise". Accounting, Organizations and Society, Vol. 19 No. 8, pp. 701-16.

Louwers, T. J., Ramsay, R. J., Sinason, D. H. (2005). Auditing and Assurance Service. New York: Mc Graw Hill.

Louwers, Timothy, et al. (2013). Auditing \& Assurance Services. Fiveth Edition. New York: McGrawHill/Irwin.

Mayangsari, Sekar. (2003). Pengaruh Keahlian Audit dan Independensi Terhadap Pendapat Audi. Sebuah Kuasieksperimen. Jurnal Riset Akuntansi Indonesia, Vol. 6, No. 1, Hal. 1-22, Januari 2003.

Mayhew, B.W., Schatzberg, J.W. and Sevcik, G.R. (2001). "The effect of accounting uncertainty and auditor reputation on auditor objectivity". 
Publisher: LPPM STIE Muhammadiyah Bandung

P-ISSN: 2541-5255, E-ISSN: 2621-5306

Volume 2 Nomor 3, September - Desember 2018

Auditing: A Journal of Practice and Theory, Vol. 20 No. 2, pp. 49-70.

McCracken, S., Salterio, S.E. and Gibbins, M. (2008). "Auditor-client management relationship and roles in negotiating financial reporting". Accounting, Organizations and Society, Vol. 33 Nos 4/5, pp. 36283.

Mulyadi. (2013). Sistem Akuntansi. Jakarta: Salemba Empat.

Murtanto dan Gudono. (1999). "Identifikasi Karakteristik-karakteristik Keahlian Audit : Profesi Akuntan Publik Di Indonesia". Jurnal Riset Akuntansi Indonesia, Volume 2 No. 1, Januari 1999.

Myers, J.N., Myers, L.A. and Omer, T.C. (2003). "Exploring the term of the auditor-client relationship and the quality of earnings: a case for mandatory auditor rotation?". Accounting Review, Vol. 78 No. 3, pp. 779-99.

Ohman, P., Ha“ckner, E., Jansson, A.-M. and Tschudi, F. (2006). "Swedish auditors' view of auditing: doing things right versus doing the right thing". European Accounting Review, Vol. 15 No. 1, pp. 89-114.

Ohman, P., Ha“ckner, E., Jansson, A.-M. and Tschudi, F. (2006). "Swedish auditors' view of auditing: doing things right versus doing the right thing". European Accounting Review, Vol. 15 No. 1, pp. 89-114.

Oliver, R.L. (1996). Satisfaction: A Behavioral Perspective on the Consumer, McGraw-Hill, New York, NY.

Pamudji, Sugeng. (2009). Pengaruh Kualitas Audit dan Auditor Baru Serta Pengalaman Bagian Akuntansi Terhadap Kepuasan Loyalitas Klien. JAAI, 13 (2), 149-165.

Pandit, G.M. (1999). “Clients' perceptions of their incumbent auditors and their loyalty to the audit firms: an empirical study", Mid-Atlantic
Journal of Business, Vol. 35 No. 4, pp. 171-88.

Parasuraman, A., Berry, L.L. and Zeithaml, V.A. (1988). "SERVQUAL: a multiple-item scale for measuring consumer perceptions of service quality", Journal of Retailing, Vol. 64 No. 1, pp. 12-40.

Porter, B. (1993). "An empirical study of the audit expectation-performance gap", Accounting and Business Research, Vol. 24 No. 93, pp. 4968.

Putri, Windasari Suhar. (2010). Pengaruh Atribut Kualitas Audit Terhadap Kepuasan Klien. Universitas Dipenogoro. Skripsi.

Rezaee, Z. (2004). "Restoring public trust in the accounting profession by developing anti-fraud education, programs and auditing". Managerial Auditing Journal, Vol. 19 No. 1, pp. 134-48.

Ruiz-Barbadillo, E., Gómez-Aguilar, N., de Fuentes-Barbara', C. and Garcia'-Benau, M.A. (2004). “Audit quality and going-concern decisionmaking process: Spanish evidence". European Accounting Review, Vol. 13 No. 4, pp. 597-620.

Shafer, W.E., Park, L.J. and Liao, W.M. (2002).

"Professionalism, organizational-professional conflict and work outcomes: a study of certified management accountants". Accounting, Auditing and Accountability Journal, Vol. 15 No. 1, pp. 46-68.

Shaub, M.K., Lawrence, J. E. (1996). "Ethics, Experience and Profesional Scepticism: A Situational Analysis." Behavioral Research in Accounting. Vol.8 : 154-174.

Shaub, Michael K and Lawrence Janice E. (1996). Ethics, Experience and Professional Skeptictsm: A Situational Analysis, Behavloral Research in accounting. Vol 8, Suppement No. 124- 157. 
Publisher: LPPM STIE Muhammadiyah Bandung

P-ISSN: 2541-5255, E-ISSN: 2621-5306

Volume 2 Nomor 3, September - Desember 2018

Suarsa, A. \& Nawawi, E. (2018) "PENGARUH RETURN ON ASSETS, DEBT TO ASSETS RATIO, DAN OPINI AUDIT TERHADAP AUDIT DELAY", Jurnal Ilmiah MEA (Manajemen, Ekonomi, \& Akuntansi ), 2(1), pp. 1-9. doi: 10.31955/jimea.vol1.iss1.pp1-9

Sunyoto, Danang. 2013. Perilaku Konsumen (Panduan Riset Sederhana untuk mengenali Konsumen). PT Buku Seru. Jakarta.

Sutton, S.G. (1993). "Towards an understanding of the factors affecting the quality of the audit process", Decision Sciences, Vol. 24 No. 1, pp. 88-105.

Tuanakota, T. M. (2011). Berpikir Kritis dalam Auditing. Jakarta: Salemba Empat.

Umar, A. and Anandarajan, A. (2004). "Dimensions of pressures faced by auditors and its impact on auditors' independence: a comparative study of the USA and Australia". Managerial Auditing Journal, Vol. 19 No. 1, pp. 99-116.

Warming-Rasmussen, B. and Jensen, L. (1998). "Quality dimension in external audit services: an external user perspective". European Accounting Review, Vol. 7 No. 1, pp. $65-82$.

Webster, Merriam. (1983). Webster's Ninth New Collegiate Dictionary, Merriam-webster Inc.

Westerdahl, S. (2005). "Vad har de fo"r sig? Om revisorers vardag och vad den betyder fo"r etik och la"rande" ("What do they do? About auditors' weekdays and what they mean for ethics and learning"), in Johansson, S.-E., Ha"ckner, E. and Wallerstedt, E. (Eds), Uppdrag revision: Revisorsprofessionen i takt med fo" rva" ntningarna? (The Task of Auditing: A Profession That Lives up to Expectations?), SNS Fo"rlag, Stockholm, pp. 45-60.

Westerdahl, S. (2005). "Vad har de fo"r sig? Om revisorers vardag och vad den betyder fo"r etik och la"rande" ("What do they do? About auditors' weekdays and what they mean for ethics and learning"), in Johansson, S.- E., Ha"ckner, E. and Wallerstedt, E. (Eds), Uppdrag revision: Revisorsprofessionen i takt med fo. rva" ntningarna? (The Task of Auditing: A Profession That Lives up to Expectations?), SNS Fo"rlag, Stockholm, pp. 45-60

Widagdo,R, S.Lesmana, dan S.A. Irwandi. (2002). Analisis Pengaruh AtributAtribut Kualitas Audit Terhadap Kepuasan Klien (Studi Empiris pada Perusahaan yang Terdaftar di Bursa Efek Jakarta). SNA 5 Semarang.p.560-574.

Wilson, T.E. Jr and Grimlund, R.A. (1990). "An examination of the importance of an auditor's reputation". Auditing: A Journal of Practice and Theory, Vol. 9 No. 1, pp. 43-59.

Windsor, C.A. and Ashkanasy, N.M. (1995). "The effect of client management bargaining power, moral reasoning development and belief in a just world on auditor independence". Accounting, Organizations and Society, Vol. 20 Nos 7/8, pp. 701-20. 